\title{
Adherence to Hydroxyurea Therapy in Patients with Sickle Cell Disease at King Khalid University Hospital in Riyadh
}

Alkanhal HN, Bakrman AK, Alzahrani AM, Alotaibi MS, Bin Salamah AA, AlHejjei SA and Al-Anazi KA*

College of Medicine and King Khalid University Hospital, King Saud University, Saudi Arabia

\begin{abstract}
Background: Sickle cell disease is associated with several systemic complications and life-threatening crises. The use of drugs that increase hemoglobin F level, such as hydroxyurea, in patients with sickle cell disease is associated with a reduction in the severity of the disease.
\end{abstract}

Aim: To compare the outcome of patients adherent to hydroxyurea with those who are poorly adherent and to determine which age group is more likely to be poorly adherent and hence suffer more complications.

Subjects and Methods: A cross-sectional study was performed at King Khalid University Hospital in Riyadh between January 01 and March 31, 2014. The study included 140 patients, 60 of them were receiving hydroxyurea therapy.

Results: Patients who were adherent to hydroxyurea treatment suffered less complications and had less frequent sickling crises than patients who were poorly adherent to therapy. Patients belonging to the age group 15 to 30 years were found to be less adherent to treatment than other age groups and consequently they suffered more complications.

Conclusion: More attention and health education should be offered to adolescents and young adults having sickle cell anemia in order for these patients to benefit from the positive impact of hydroxyurea on the disease outcome.

Keywords: Sickle cell disease; Sickle cell crises; Hydroxyurea; Hemoglobin S; Hemoglobin F; Adherence to treatment

\section{Introduction}

Sickle cell disease (SCD) is an autosomal recessive disease characterized by production of hemoglobin $(\mathrm{Hb}) \mathrm{S}$ which is poorly soluble and becomes polymerized when deoxygenated [1]. Hb S results from a point mutation in $\beta$-globin chain of human $\mathrm{Hb}$ (Glu 6 Val) where the sixth amino acid, glutamine, is substituted by valine [13]. This genetic mutation causes red blood cells (RBCs) to acquire a sickle shape under conditions of hypoxia resulting in a wide range of complications such as veno-occlusive crises, hemolytic episodes, stroke, acute chest syndrome and susceptibility to various infections [3].

Hydroxyurea is the most commonly used targeted therapy that increases $\mathrm{Hb} \mathrm{F}$ production in patients with SCD [2,4,5]. Indications for using hydroxyurea in patients with SCD include: (1) frequent painful crises (2) recurrent chest syndrome or other severe venoocclusive events, (3) severe, symptomatic and chronic anemia, and (4) reduction of pain, dactylitis, acute chest syndrome and anemia in children and adolescents [6,7]. The use of hydroxyurea in patients with SCD has the following beneficial effects: (1) increased production of $\mathrm{Hb} \mathrm{F}$ with a concomitant reduction in the intracellular concentration of $\mathrm{Hb} \mathrm{S}$ that can lead to an increase in total $\mathrm{Hb}$ concentration and decreased hemolysis with the release of free $\mathrm{Hb}$, (2) reduction in white blood cell (WBC) count and reduction in the expression of cell adhesion molecules that contribute to diminution of veno-occusive crises and other complications, (3) reduction in the rate of infectious complications, and (4) significant reductions in the frequencies of hospitalization and blood transfusion as well as in the costs of medical care $[4,6-9]$. These beneficial effects have translated into reduction in the severity of SCD, decreased mortality and improved survival as well as quality of life $[4,6-9]$.

\section{Subjects and Methods}

\section{The study design}

A quantitative, observational, cross-sectional study was performed at King Khalid University Hospital (KKUH) in Riyadh between January 01 and March 31, 2014. The study included 140 patients with SCD attending the hematology out-patient clinics. Sixty of these patients fulfilled the criteria of the study as they were having regular follow up and they were on hydroxyurea treatment. These patients were interviewed and they were requested to answer specific questions included in a questionnaire. Their medical records and their laboratory data were reviewed. In order to obtain all the necessary details, the patients and their families were contacted by phone.

\section{Hospital and institutional approval}

KKUH is a tertiary care center comprising 984 beds with several medical as well as surgical specialities and sub-specialities that include hematology, oncology in addition to intensive care and high

*Corresponding author: Khalid Ahmed Al-Anazi, Consultant Hemato-Oncologist, Section of Adult Hematology and Oncology, Department of Medicine, College of Medicine and King Khalid University Hospital, King Saud University, P.O. Box: 2925, Riyadh 11461, Saudi Arabia, Tel: 966- 011-4671546, Fax: 966-011-4671546; E-mail: kaa_alanazi@yahoo.com

Received November 11, 2014; Accepted December 26, 2014 Published December 29, 2014

Citation: Alkanhal HN, Bakrman AK, Alzahrani AM, Alotaibi MS, Bin Salamah AA, et al. (2014) Adherence to Hydroxyurea Therapy in Patients with Sickle Cell Disease at King Khalid University Hospital in Riyadh. J Blood Disorders Transf 5: 242. doi: 10.4172/2155-9864.1000242

Copyright: (c) 2014 Alkanhal HN, et al. This is an open-access article distributed under the terms of the Creative Commons Attribution License, which permits unrestricted use, distribution, and reproduction in any medium, provided the original author and source are credited. 
dependency units. The study was initially approved by the department of family and community medicine and other concerned departments. The patients participating in the study received enough explanations and knowledge about the study and informed consents were taken from them. Subsequently, the study was approved by the institutional review

\begin{tabular}{|c|c|}
\hline Item & Details \\
\hline Number of patients & 60 \\
\hline Gender & 32 males and 28 females \\
\hline Age & Range:11-42 years; median:19 years \\
\hline Original residence & $\begin{array}{ll}\text { - } & \text { Southern province: } 42 \text { patients }(70 \%) \\
\text { - } & \text { Eastern province: } 6 \text { patients }(10 \%) \\
\text { - } & \text { Other regions: } 12 \text { patients }(20 \%)\end{array}$ \\
\hline $\begin{array}{l}\text { Family history of } \\
\text { sickle cell disorders }\end{array}$ & 40 patients $(66.7 \%)$ \\
\hline $\begin{array}{l}\text { Adherence to } \\
\text { drug therapy }\end{array}$ & $\begin{array}{ll}\text { - } & \text { Low: } 22 \text { patients }(36.7 \%) \\
\text { - } & \text { High: } 38 \text { patients }(63.3 \%)\end{array}$ \\
\hline $\begin{array}{l}\text { Reason for low } \\
\text { adherence to therapy }\end{array}$ & $\begin{array}{l}\text { - } \quad \text { Forgetting drug and carelessness: } \\
16 \text { patients }(73 \%) \\
\text { - } \quad \text { Lack of knowledge about the drug: } \\
7 \text { patients }(32 \%)\end{array}$ \\
\hline
\end{tabular}

Table 1: Shows demographic and other basic data related to the study patients.

\begin{tabular}{|c|c|c|c|}
\hline Age in years & $\mathbf{1 1}$ to $<\mathbf{1 5}$ & $\mathbf{1 5}$ to $\mathbf{3 0}$ & $>\mathbf{3 0}$ \\
\hline Number of patients & 21 & 30 & 9 \\
\hline Males & 13 & 16 & 3 \\
\hline Females & 8 & 14 & 6 \\
\hline Low adherence & $33 \%$ & $43 \%$ & $22 \%$ \\
\hline High adherence & $67 \%$ & $57 \%$ & $78 \%$ \\
\hline
\end{tabular}

Table 2: Shows adherence to hydroxyurea therapy in the study patients belonging to different age groups.

\begin{tabular}{|c|c|c|c|c|}
\hline $\begin{array}{l}\text { Variable per } \\
\text { year }\end{array}$ & $\begin{array}{c}\text { Level of } \\
\text { adherence }\end{array}$ & $\begin{array}{l}\text { Number of } \\
\text { episodes }\end{array}$ & Mean (standard deviation) & $P$ value \\
\hline \multirow{2}{*}{$\begin{array}{l}\text { Sickle } \\
\text { cell crises }\end{array}$} & High & 22 & $2.4839(1.56)$ & \multirow{2}{*}{0.001} \\
\hline & Low & 31 & $3.9091(1.4)$ & \\
\hline \multirow{2}{*}{$\begin{array}{c}\text { Hospital } \\
\text { admissions }\end{array}$} & High & 22 & $2.1935(1.37)$ & \multirow{2}{*}{0.004} \\
\hline & Low & 31 & $3.3182(1.32)$ & \\
\hline \multirow{2}{*}{$\begin{array}{c}\text { Blood } \\
\text { transfusions }\end{array}$} & Low & 22 & 2.3684 & \multirow{2}{*}{0.136} \\
\hline & High & 38 & 3.0455 & \\
\hline
\end{tabular}

Table 3: Shows sickle cell disease consequences as reflected by adherence to hydroxyurea.

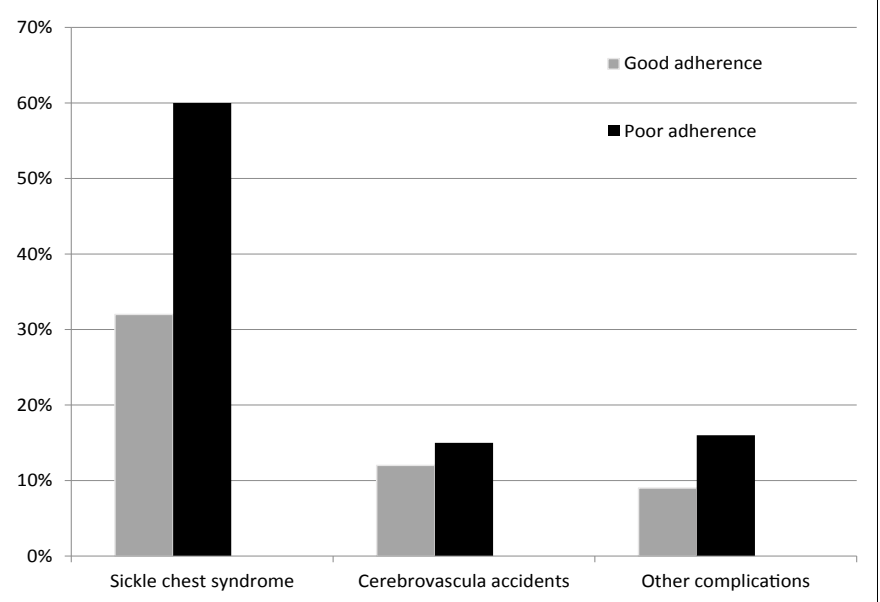

Figure 1: Shows complications of sickle cell disease according to their level of adherence to hydroxyurea therapy. board (IRB) at the college of medicine, King Saud University in Riyadh and was given this number: E-14-1325.

\section{Patients and data collection}

Out of the patients with SCD who had regular follow up at the hematology out-patient clinics at KKUH, the records of 140 patients were randomly selected. The selected patients were contacted by phone and they were requested to participate in the study. They were given a questionnaire and they were requested to answer the questions included in that questionnaire. Seventy seven (55\%) of these patients responded and answered the questionnaire. Seventeen of these patients were excluded from the study as they were not on hydroxyurea therapy. So, data belonging to 60 patients were finally included the study analysis. The data sheet and questionnaire included a long list of items including: (1) demographic information such as age, gender, occupation and original area of residence, (2) details of SCD including: date of diagnosis, severity of disease as reflected by the frequency of hospital admissions and sickling crises per year, the frequency of blood transfusions per year and iron overload, and (3) details of hydroxyurea therapy including: duration, dose, adverse effects encountered, adherence level and follow-up of $\mathrm{HbF}$ and mean corpuscular volume (MCV) levels to judge the level of adherence to therapy. Modified Morisky Medication Adherence Scale (MMMAS) was used to assess adherence of patients to hydroxyurea [10]. Patients who scored $\geq 4$ on MMMAS were considered to have high adherence and those scoring < 4 were considered to have low adherence.

\section{Statistics}

Descriptive statistics were calculated for all variables using the Statistical Package for the Social Sciences, version 20 (SPSS Inc., Chicago, IL, USA. A P-value of $\leq 0.5$ was considered statistically significant. For the number of hospital admissions, blood transfusions and sickling crises, student t-test was used to detect statistically significant difference between the two means (high adherence and low adherence groups of patients).

\section{Results}

The 60 patients with SCD included in the study were on hydroxyurea therapy and they were having regular follow up at KKUH. Out of these 60 patients 32 were males and 28 were females. Their ages ranged between 11 and 42 years with a median age of 19 years. Seventy percent of our patients were originally from the southern region and two thirds of them had family history of sickle cell disorders ie trait or disease. The level of adherence to hydroxyurea treatment was low or poor in 22 patients $(36.7 \%)$ and was high or good in 38 patients (63.3\%) (Table 1). Patients belonging to the age group 15-30 years had the highest level of poor adherence to therapy and hence they suffered more complications related to their SCD. The frequencies of sickling crises and hospital admissions were significantly higher in patients having low adherence levels. However, no statistical difference between the two groups of patients was found in relation to the frequency of blood transfusions (Tables 2, 3 and Figure 1).

The reasons for poor adherence to therapy were mainly: forgetting to take the prescribed therapy, carelessness from the side of the patient, lack of knowledge about the beneficial effects of hydroxyurea on SCD and having exaggerated information about the adverse effects of the drug particularly those related to fertility, teratogenicity and carcinogenesis (Table 1). Adherence to hydroxyurea was confirmed in the laboratory by having low MCV and HbF levels in patients with poor 
Citation: Alkanhal HN, Bakrman AK, Alzahrani AM, Alotaibi MS, Bin Salamah AA, et al. (2014) Adherence to Hydroxyurea Therapy in Patients with Sickle Cell Disease at King Khalid University Hospital in Riyadh. J Blood Disorders Transf 5: 242. doi: 10.4172/2155-9864.1000242

Page 3 of 5

\begin{tabular}{|l|c|c|c|c|c|c|c|}
\hline $\begin{array}{c}\text { Level of } \\
\text { Adherence }\end{array}$ & $\begin{array}{c}\text { Number of } \\
\text { patients }\end{array}$ & Evaluable patients & Range fL & Median fL & Evaluable patients & Range \% & Median $\%$ \\
\hline High adherence & 38 & 38 & $90-115$ & 105 & 38 & 15 \\
\hline Low adherence & 22 & 20 & $70-95$ & 81 & 14 & $0.0-5.0$ \\
\hline
\end{tabular}

Normal range of MVC [mean corpuscular volume]: $80-100$ femtoliters (fL)

Normal range of $\mathrm{Hb} \mathrm{F}$ [hemoglobin $\mathrm{F}$ level]: 0.8-2.0\%

Table 4: Shows MCV and $\mathrm{Hb}$ F levels in the study patients divided according to adherence level.

or low adherence and by having high MCV and HbF levels in patients with high adherence to the prescribed medication (Table 4).

\section{Discussion}

Patients with SCD are at risk of developing a number of life-threating crises and the disease may be complicated by adverse consequences that may involve any body organ [1-3,11-13]. Therefore, care of patients with SCD is a difficult task that requires a multidisciplinary approach $[1,2,13]$. Management of patients with SCD can be divided into: (1) general measures, such as analgesia and blood transfusions, that can serve as long-term care as well as crisis intervention, (2) specific and targeted therapies, such as hydroxyurea, that are aimed at prevention and management of complications, (3) potentially curative treatments such as gene replacement therapy as well as various forms of hematopoietic stem cell transplantation, and (4) preventive measures such as family and genetic counselling [1,2,14-16].

The use of hydroxyurea has been associated with systemic adverse effects, but these side effects are not usually severe [17-21]. A three year follow up of patients with SCD treated with hydroxyurea showed no major short or medium-term toxicity and a 9 year follow up study showed that no serious adverse effects were encountered on long-term use of the drug $[9,18]$. Predictors of response to hydroxyurea therapy include: (1) reduction in the number of veno-occlusive crises and complications of SCD, (2) increase in normal $\mathrm{Hb}$ level, $\mathrm{Hb}$ F level, $\mathrm{MCV}$, mean corpuscular hemoglobin $(\mathrm{MCH})$, mean reticulocyte volume and percentage of F-cells, and (3) increase in the urinary level of hydroxyurea as measured by mass spectrometry [22-26]. In our study, patients with high adherence to hydroxyurea therapy had comparatively higher MCV and $\mathrm{Hb}$ F values than those with low adherence levels.

The use of hydroxyurea in children with SCD is significantly associated with: (1) sickle genotype, (2) better parental knowledge about the major therapeutic effects of the drug, and (3) institution of this therapy by hematologists and provision of the drug to symptomatic patients [5].

Adherence to hydroxyurea can be measured by: (1) pharmacy refills, (2) MMMAS, and (3) visual analogue scale [27]. Pharmacy refills and MMMAS may be helpful in identifying children at risk of poor response due to non-adherence and children with good adherence but having poor response due to biologic factors such as pharmacodynamics [27]. Studies have shown that close adherence to prescribed hydroxyurea therapy is necessary to maximize the efficacy of the drug and that adherence to treatment improves health-related quality of life $[28,29]$. In a large retrospective study that was conducted in North Carolina, USA and that included 312 patients with sickle cell anemia (SCA) treated with hydroxyurea, the following results were obtained: (1) adherence to treatment was generally suboptimal, as nearly two thirds of the study population were classified as nonadherent to therapy, and (2) adherence to hydroxyurea was associated with: reduced risk of hospitalization, reduction in the number of visits to the emergency room, reduction in the frequency of venoocclusive crises and reduction in health care costs [30]. In our study, high adherence level was encountered in $63.3 \%$ of patients and this was mainly seen in children and in adults, whilst low adherence level was found in $36.7 \%$ of patients and it was most frequently encountered in adolescents and young adult i.e. patients belonging to the age group 15 to 30 years (Tables 1 and 2). The following are possible explanations of our findings: children are usually supervised by their parents to take their medications, patients $>30$ years of age are mature enough to take their treatment without supervision, whilst teenagers and young adults might not accept direct supervision to take prescribed drugs as they like to be independent. Having rather exaggerated ideas about the side effects of the drug and not having adequate information on the safety profile of hydroxyurea could have contributed to the low adherence to therapy. Infertility, teratogenicity and cancinogenesis issues related to the use of hydroxyurea were the main concerns of patients and consequently they were the reasons of poor adherence to therapy.

In a multicenter, double-blinded, placebo-controlled study on the efficacy of hydroxyurea therapy in SCA patients that included 150 patients treated with hydroxyurea and that was performed in USA in 1995, the results of follow up for 2 years showed: (1) half of the hydroxyurea-assigned patients had long-term increment in $\mathrm{Hb} \mathrm{F}$, and (2) bone marrow reserve or ability to withstand hydroxyurea therapy was important for sustained $\mathrm{Hb} \mathrm{F}$ increase during treatment with hydroxyurea [31]. Extended follow up of patients for 17.5 years showed significant reduction in mortality and safety of the drug on long-term use [32]. Barriers to adherence to hydroxyurea treatment include: high frequency and length of clinic visits, disruption of school and work and lack of resources [33]. Facilitators of adherence include: health benefits of therapy, social support systems, medication reminders and positive clinic experiences [33]. In addition to health education, the following methods have been shown to improve compliance with treatment: (1) multimedia communication for hospitalized patients with their teachers and work colleagues, (2) integration of interactive web-based technology to assess adherence to therapy, (3) electronic DOT, and (4) coaching very young children for swallowing hydroxyurea capsules [33-37].

Over the last 30 years, substantial experience has accumulated regarding the safety and efficacy of hydroxyurea in patients with SCD and strong evidence supports its efficacy in reducing the frequency of veno-occlusive crises, acute chest syndrome, hospitalizations and blood transfusions in patients with SCD [38-41]. Thus, hydroxyurea is considered as an important advance in the treatment of SCD as it is the only widely used drug that modifies the pathogenesis of the disease $[38,40]$. Although questions remain regarding its long-term risks and benefits, current evidence suggests that many young patients with SCD should receive hydroxyurea [38-41].

We acknowledge that our study has few limitations including being a cross-sectional, observational study and that the number of patients included in the study was rather low. However, more efforts are needed to improve adherence to hydroxyurea in order to decrease the complications of SCD. 
Citation: Alkanhal HN, Bakrman AK, Alzahrani AM, Alotaibi MS, Bin Salamah AA, et al. (2014) Adherence to Hydroxyurea Therapy in Patients with Sickle Cell Disease at King Khalid University Hospital in Riyadh. J Blood Disorders Transf 5: 242. doi: 10.4172/2155-9864.1000242

\section{Conclusions and Recommendations}

Hydroxyurea therapy has proven to be effective in reducing the complications in patients with SCD and it has significantly improved the quality of life of these patients. As poor adherence to therapy was most frequently encountered in adolescents and young adults with SCD, particular attention should be given to this group of patients. Health education about: complications of the disease, available therapeutic modalities, the role of hydroxyurea and other targeted therapies in reducing the complications of SCD as well as the importance of adherence to treatment should be given enough attention.

\section{Acknowledgement}

The authors of this manuscript like to thank all the medical, nursing and technical staff at KKUH for their support and cooperation. We also like to extend our thanks to our patients and their families.

\section{Conflict of Interest}

The authors of the manuscript declare that they have no conflict of interest. All the authors listed participated in: the design of the study, data collection interviewing patients, literature reviews and writing as well as reviewing the manuscript. The authors also declare that they have read and approved the final and submitted version of the manuscript.

\section{References}

1. Kaur M, Dangi CBS, Singh M (2013) An overview of sickle cell disease profile. Asian J Pharmaceut Clin Res 6: 25-37.

2. Bender MA, Hobbs W (2012) Sickle cell disease. Gene Reviews $®$ [Internet] NCBI Bookshelf 2012. Pagon RA, Adam MP, Ardinger HH, et al. (ed.) Seatle (WA): University of Washington, Seatle, pp: 1993-2011

3. Driss A Asare KO, Hibbert JM, Gee BE, Adamkiewicz TV, et al. (2009) Sickle Cell Disease in the Post Genomic Era: A Monogenic Disease with a Polygenic Phenotype. Genomics Insights 2009: 23-48.

4. Strouse JJ Heeney MM (2012) Hydroxyurea for the treatment of sickle cell disease: efficacy, barriers, toxicity, and management in children. Pediatr Blood Cancer 59: 365-371.

5. Oyeku SO Driscoll MC, Cohen HW, Trachtman R, Pashankar F, et al. (2013) Parental and other factors associated with hydroxyurea use for pediatric sickle cell disease. Pediatr Blood Cancer 60: 653-658.

6. Rodgers GP (2014) Hydroxyurea and other disease-modifying therapies in sickle cell disease. In: Schrier SL, Mahoney DH, Tirnauer JS (Eds.), Topic 707 version 38.0, pp: 1-22.

7. Yawn BP Buchanan GR, Afenyi-Annan AN, Ballas SK, Hassell KL, et al. (2014) Management of sickle cell disease: summary of the 2014 evidence-based report by expert panel members. JAMA 312: 1033-1048.

8. Silva-Pinto AC Angulo IL, Brunetta DM, Neves FI, Bassi SC, et al. (2013) Clinical and hematological effects of hydroxyurea therapy in sickle cell patients: a single-center experience in Brazil. Sao Paulo Med J 131: 238-243.

9. Steinberg MH Barton F, Castro O, Pegelow CH, Ballas SK, et al. (2003) Effect of hydroxyurea on mortality and morbidity in adult sickle cell anemia: risks and benefits up to 9 years of treatment. JAMA 289: 1645-1651.

10. Al-Qazaz HKh Hassali MA, Shafie AA, Sulaiman SA, Sundram S, et al. (2010) The eight-item Morisky Medication Adherence Scale MMAS: translation and validation of the Malaysian version. Diabetes Res Clin Pract 90: 216-221.

11. Schnog JB Duits AJ, Muskiet FA, ten Cate H, Rojer RA, et al. (2004) Sickle cell disease; a general overview. Neth J Med 62: 364-374.

12. Vichinsky EP (2014) Overview of the clinical manifestations of sickle cell diease, In: : Schrier SL, Tirnauer JS (Eds.), Topic 7119, version 26.0, pp: 1-14.

13. Ballas SK Kesen MR, Goldberg MF, Lutty GA, Dampier C, et al. (2012) Beyond the definitions of the phenotypic complications of sickle cell disease: an update on management. ScientificWorldJournal 2012: 949535.

14. Field JJ, Vichinsky EP, DeBaun MR (2014) Overview of the management and prognosis of sickle cell disease. UpToDate. Edited by Schrier SL, Mahoney Jr DH and Tirnauer JS. Topic 7114, version 31.0, pp: 1-33.

15. Townes TM (2008) Gene replacement therapy for sickle cell disease and other blood disorders. Hematology Am Soc Hematol Educ Program .
16. Shenoy S (2011) Hematopoietic stem cell transplantation for sickle cell disease: current practice and emerging trends. Hematology Am Soc Hematol Educ Program 2011: 273-279.

17. Ballas SK, Singh P, Adams-Graves P, Wordell CJ (2013) Idiosyncratic side effects of hydroxyurea in patients with sickle cell anemia. J Blood Disorders Transf 4: 5 .

18. de Montalembert M, Begue P, Bernaudin F, Thuret I, Bachir D, et al, (1999) Preliminary report of a toxicity of hydroxyurea in sickle cell disease. Arch Dis Child 81: 437-439.

19. Jones KM Niaz MS, Brooks CM, Roberson SI, Aguinaga MP, et al. (2009) Adverse effects of a clinically relevant dose of hydroxyurea used for the treatment of sickle cell disease on male fertility endpoints. Int J Environ Res Public Health 6: 1124-1144.

20. Lukusa AK Vermylen C, Vanabelle B, Curaba M, Brichard B, et al. (2009) Bone marrow transplantation or hydroxyurea for sickle cell anemia: long-term effects on semen variables and hormone profiles. Pediatr Hematol Oncol 26: 186-194.

21. Grigg A (2007) Effect of hydroxyurea on sperm count, motility and morphology in adult men with sickle cell or myeloproliferative disease. Intern Med J 37: 190-192.

22. Borba R Lima CS, Grotto HZ (2003) Reticulocyte parameters and hemoglobin $F$ production in sickle cell disease patients undergoing hydroxyurea therapy. J Clin Lab Anal 17: 66-72.

23. Ware RE Eggleston $B$, Redding-Lallinger R, Wang WC, Smith-Whitley $K$, et al. (2002) Predictors of fetal hemoglobin response in children with sickle cell anemia receiving hydroxyurea therapy. Blood 99: 10-14.

24. Ma Q Wyszynski DF, Farrell JJ, Kutlar A, Farrer LA, et al. (2007) Fetal hemoglobin in sickle cell anemia: genetic determinants of response to hydroxyurea. Pharmacogenomics J 7: 386-394.

25. Mach Queiroz AM, de Castro Lobo CL, do Nascimento EM, de Braganca Pereira B, Bonini-Domingo CR, et al. (2013) The mean corpuscular volume and hydroxyurea in Brazilian patients with sickle cell anemia: a surrogate marker of compliance. J Blood Disorders Transf 4: 157.

26. Dalton RN Turner C, Dick M, Height SE, Awogbade M, et al. (2005) The measurement of urinary hydroxyurea in sickle cell anaemia. $\mathrm{Br} \mathrm{J}$ Haematol 130: $138-144$

27. Thornburg CD Calatroni A, Telen M, Kemper AR (2010) Adherence to hydroxyurea therapy in children with sickle cell anemia. J Pediatr 156: 415419.

28. Drotar D (2010) Treatment adherence in patients with sickle cell anemia. J Pediatr 156: 350-351.

29. Al Jaouni SK Al Muhayawi MS, Halawa TF, Al Mehayawi MS (2013) Treatment adherence and quality of life outcomes in patients with sickle cell disease. Saudi Med J 34: 261-265.

30. Candrilli SD O'Brien SH, Ware RE, Nahata MC, Seiber EE, et al. (2011) Hydroxyurea adherence and associated outcomes among Medicaid enrollees with sickle cell disease. Am J Hematol 86: 273-277.

31. Steinberg MH Lu ZH, Barton FB, Terrin ML, Charache S, et al. (1997) Fetal hemoglobin in sickle cell anemia: determinants of response to hydroxyurea. Multicenter Study of Hydroxyurea. Blood 89: 1078-1088.

32. Steinberg MH McCarthy WF, Castro O, Ballas SK, Armstrong FD, et al. (2010 The risks and benefits of long-term use of hydroxyurea in sickle cell anemia: $A$ 17.5 year follow-up. Am J Hematol 85: 403-408.

33. Boateng L, Puffer E, Allen J, Bonner M, Thornburg CD (2013) Adherence to secondary stroke prevention in children with sickle cell anemia: family and child perspectives. J Blood Disorders Transf 4: 148.

34. Grove J, Grove O, Michie C (2013) The real effects of sickle cell disease on children and adolescents. West London Med J 6: 11-17.

35. Crosby LE Barach I, McGrady ME, Kalinyak KA, Eastin AR, et al. (2012) Integrating interactive web-based technology to assess adherence and clinical outcomes in pediatric sickle cell disease. Anemia 2012: 492428.

36. Creary SE, Gladwin MT, Byrne M, Hildesheim M, Krishnamurti L (2014) A pilot study of electronic directly observed therapy to improve hydroxyurea adherence in pediatric patients with sickle-cell disease. Pediatr Blood Cancer 61: 1068-1073. 
Citation: Alkanhal HN, Bakrman AK, Alzahrani AM, Alotaibi MS, Bin Salamah AA, et al. (2014) Adherence to Hydroxyurea Therapy in Patients with Sickle Cell Disease at King Khalid University Hospital in Riyadh. J Blood Disorders Transf 5: 242. doi: 10.4172/2155-9864.1000242

37. Bekele E Thornburg CD, Brandow AM, Sharma M, Smaldone AM, et al. (2014) Do difficulties in swallowing medication impede the use of hydroxyurea in children? Pediatr Blood Cancer 61: 1536-1539.

38. Brawley OW, Cornelius LJ, Edwards LR, Gamble VN, Green BL, et al. (2008) National Institutes of Health Consensus Development Conference Statement: hydroxyurea treatment for sickle cell disease. Ann Intern Med 148: 932-938.

39. Ware RE (2010) How I use hydroxyurea to treat young patients with sickle cell anemia. Blood 115: 5300-5311.
40. Mulaku M Opiyo N, Karumbi J, Kitonyi G, Thoithi G, et al. (2013) Evidence review of hydroxyurea for the prevention of sickle cell complications in lowincome countries. Arch Dis Child 98: 908-914.

41. Segal JB, Strouse JJ, Beach MC, Haywood C, Witkop C, et al. (2008) Hydroxyurea for the treatment of sickle cell disease. Evidence Report Technology Assessment Number 165 